\title{
Synthesis, Characterization and Antimicrobial Evaluation of Novel 1-[(1-Phenyl-1h-Tetrazol-5-yl-imino)-Methyl]-Naphthalen-2-ol and Its $\mathrm{Cu}(\mathrm{II}), \mathrm{Co}(\mathrm{II})$ Complexes
}

\author{
MARIYAM $^{1,2 *}$ and SISKA OKTAPIANTI ${ }^{2}$ \\ 'Department of Chemistry, College of Science, Institut Teknologi SumateraJl. Terusan Ryacudu, \\ Lampung Selatan 35365, Indonesia. \\ ${ }^{2}$ Department of Chemistry, College of Science, Osmania University Main Road, Amberpet, \\ Hyderabad, Telangana 500007, India. \\ *Corresponding author E-mail: mariyam @ ki.itera.ac.id \\ http://dx.doi.org/10.13005/ojc/340346
}

(Received: January 07, 2018; Accepted: June 06, 2018)

\begin{abstract}
Novel 1-[(1-Phenyl-1H-tetrazol-5-ylimino)-methyl]-naphthalen-2-ol (PTMN) ligand, [Cu(PTMN) $\mathrm{ClH}_{2} \mathrm{O}$ ] and [Co(PTMN) $\left.\mathrm{ClH}_{2} \mathrm{O}\right]$ complexes have been synthesized. Characterization of the obtained compounds were performed by ${ }^{1} \mathrm{H}-\mathrm{NMR}, \mathrm{FT}-\mathrm{IR}, \mathrm{UV}$-Vis, Mass spectrometry and thermo-analytical study. The morphology of compounds were determined by SEM, while EDX study was employed to identify elements in ligand and the metal complexes. Metal-ligand compositions were analyzed spectrophotometrically using Job's continuous-variation method. $\mathrm{pH}$-metric technique was carried out to give the quantity of dissociable protons and protonation sites in the obtained compound. The ligand $\left[\mathrm{Cu}(\mathrm{PTMN}) \mathrm{ClH}_{2} \mathrm{O}\right]$ and $\left[\mathrm{Co}(\mathrm{PTMN}) \mathrm{ClH}_{2} \mathrm{O}\right]$ complexes were tested for in vitro antimicrobial properties against YEPDA, Gram-positive and negative bacteria. It was observed that metal complexes showed enhanced antimicrobial potential as compared to the free ligand. In addition, $[\mathrm{Cu}(\mathrm{PTMN})$ $\mathrm{ClH}_{2} \mathrm{O}$ complex indicated greater antimicrobial activity against most of microbial strains as compared to the ligand and $\left[\mathrm{Co}(\mathrm{PTMN}) \mathrm{ClH}_{2} \mathrm{O}\right]$ complex.
\end{abstract}

Keywords: Synthesis, Tetrazole, Cu(II), Co(II) complexes, Electronic spectra, Antimicrobial activity.

\section{INTRODUCTION}

Heterocyclic compounds play important role in organic chemistry because of their flexibility and ability to respond many demands of biochemical systems. Heterocyclic is the majority of pharmaceuticals and biologically active compound ${ }^{1}$.
Among heterocyclic compounds, tetrazole has received significant interest in the development of the synthesis of pharmacologically active drugs. Tetrazole and its derivatives have taken much more of interest in the past years due to their specific structure and their functions as antihypertensive, anticonvulsant, antifungal, antibacterial and anticancer agents ${ }^{2-6}$.

This is an Open Access article licensed under a Creative Commons Attribution-Non Commercial-Share Alike 4.0 International License (https://creativecommons.org/licenses/by-nc-sa/4.0/), which permits unrestricted Non Commercial use, distribution and reproduction in any medium, provided the original work is properly cited. 
In the field of antibiotic studies, tetrazole has been used as promising material for the treatment of bacterial infection. Advancement of tetrazole in chemistry has been widely correlated with large-scale application of those compounds in pharmacy, agriculture and industry etc ${ }^{2-13}$. However, efforts to further studies must be done to improve the functionality of tetrazole derivatives.

In the previous work, we have synthesized and characterized metal complexes of tetrazole imine base 4-Chloro-2-[(1-phenyl-1H-tetrazol-5ylimino)-methyl] phenol (Cl-PTMP) and revealed its antimicrobial activity ${ }^{14}$. In the present work, synthesis, characterization and antimicrobial evaluation of novel 1-[(1-Phenyl-1H-tetrazol-5ylimino)-methyl]-naphthalen-2-ol (PTMN) has investigated. It is confirmed that novel1-[(1-Phenyl1H-tetrazol-5-ylimino)-methyl]-naphthalen-2-ol (PTMN) showed more antimicrobial activity than previous compound.

\section{MATERIALS AND METHODS}

\section{Materials}

All chemicals used are analytical grade. 1-phenyl-1H-tetrazol-5-amine, 2-hydroxy-1naphthaldehyde, methanol, $\mathrm{CuCl}_{2} \cdot 2 \mathrm{H}_{2} \mathrm{O}, \mathrm{CoCl}_{2} \cdot 6 \mathrm{H}_{2} \mathrm{O}$, 1,4-dioxane, $\mathrm{NH}_{4} \mathrm{OH}$, nutrient agar (Merck \& Co.), non-resistant strains of microba (Bacillus subtilis, Escherichia coli, Pseudomonas aeruginosa, Klebsiella pneumoniae, Staphylococcus aureus, and Saccharomyces cerevisiae) was obtained from microbiology laboratory, Department of Microbiology, Osmania University, India.

\section{Instrumentation}

The particle size and morphology of title compounds were recorded by using ZEISSGEMINI SEM. The elemental composition was analyzed by INCA EDX instrument. Thermal analysis were recorded by TGA and DTA instrument (Polmon model No. MP-90). Mass spectra was recorded on VG AUTOSPEC. Electronic spectra was investigated using Shimadzu UV-1800 UltravioletVisible spectrophotometer. ${ }^{1} \mathrm{H}-\mathrm{NMR}$ and Infrared spectra were recorded using Varian Gemini unity spectrometer and Perkin-Elmer 337 Spectrometer respectively. $\mathrm{pH}$ metry measurement was set using a digital Elico LI $120 \mathrm{pH}$ meter in conjuction with combined glass and Calomel electrode.

\section{Procedure}

Preparation of Ligand PTMN (1-[(1-Phenyl-1Htetrazol-5-ylimino)-methyl]-naphthalen-2-ol)

Equimolar ratio of 1-phenyl-1H-tetrazol5-amine $(0.75 \mathrm{~g}, 0.00465 \mathrm{~mol})$ and 2-hydroxy1 -naphthaldehyde $(0.8010 \mathrm{~g}, 0.00465 \mathrm{~mol})$ were dissolved in methanol. The solution was refluxed for 3-4 $\mathrm{h}$, at constant temperature about $60-70^{\circ} \mathrm{C}$. The reaction progress was monitored by thin layer chromatography. Methanol was added to the resulting compound for recrystallization to yield pure compound.

Yellow solid. Yield $=58 \% \cdot m \cdot p=220^{\circ} \mathrm{C}$ UV-Vis (200-700 nm); ( $\lambda: \mathrm{nm}):(339 \mathrm{~nm})(395 \mathrm{~nm})$ (486 nm). FT-IR $\left(\mathrm{KBr}, \mathrm{cm}^{-1}\right) ; 3058\left(v_{\mathrm{C}}=_{\mathrm{H}}\right): 1607\left(v_{\mathrm{C}=\mathrm{N}}\right)$. MS $(\mathrm{M}+\mathrm{H})+\mathrm{m} / \mathrm{z}: 316.1 \mathrm{H}-\mathrm{NMR}\left(\mathrm{CDCl}_{3}\right)$, ppm: $\delta=13.8$ $(\mathrm{OH}), \delta=7.2-8.4$ (aromatic proton), $\delta=10(\mathrm{~N}=\mathrm{CH})$.

\section{Preparation of Metal Complexes}

$1 \mathrm{~mol}$ for each metal chloride $\left(\mathrm{CuCl}_{2} \cdot 2 \mathrm{H}_{2} \mathrm{O}\right.$ and $\mathrm{CoCl}_{2} \cdot 6 \mathrm{H}_{2} \mathrm{O}$ ) were dissolved in methanol and added to a solution of PTMN ligand in dioxan. Methanolic ammonia was added to maintain $\mathrm{pH}$ of the solution. The solution was refluxed $\operatorname{for}^{10-12} \mathrm{~h}$, at $50-60^{\circ} \mathrm{C}$. Further washed with dioxan and methanol.<smiles>Nc1nnnn1-c1ccccc1</smiles>

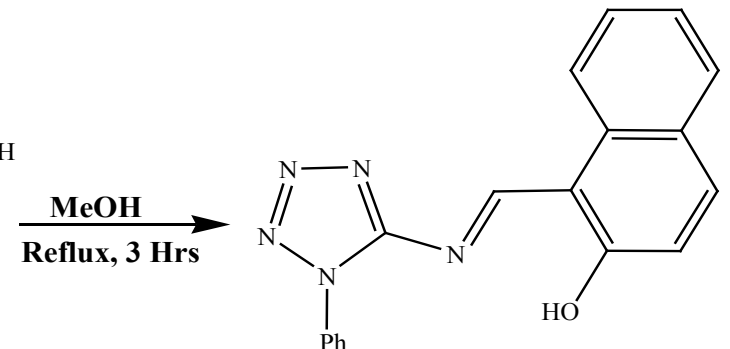

Scheme 1. The synthesis route of the ligand (PTMN) 


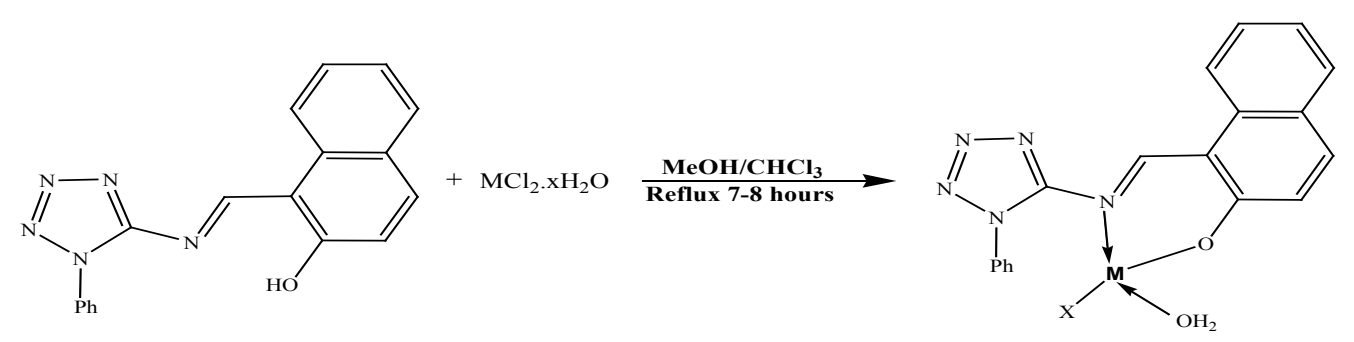

$\mathrm{M}=\mathrm{Cu}(\mathrm{II}), \mathbf{C o}(\mathrm{II})$

Scheme 2. The synthesis route of the $\left[\mathrm{Cu}(\mathrm{PTMN}) \mathrm{ClH}_{2} \mathrm{O}\right]$ and $\left[\mathrm{Co}(\mathrm{PTMN}) \mathrm{ClH}_{2} \mathrm{O}\right]$ complexes

\section{Antimicrobial evaluation}

The in vitro antimicrobial testing of ligand and $\left[\mathrm{Cu}(\mathrm{PTMN}) \mathrm{ClH}_{2} \mathrm{O}\right]$ and $\left[\mathrm{Co}(\mathrm{PTMN}) \mathrm{ClH}_{2} \mathrm{O}\right]$ complexes were assayed against non-resistant strain of Gram positive (Bacillus subtilis and Staphylococcus aureus), Gram negative (Klebsiella pneumoniae, Pseudomonas aeruginosa and Escherichia coli) bacteria and yepda (Saccharomyces cerevisiae). The microba were spreaded on nutrient agar and yeast extract peptone dextrose agar medium respectively. $20 \mu \mathrm{l}$ of each compound by the concentration of $1 \mathrm{mg} / 1 \mathrm{ml}$ were inoculated into the wells and incubated process at $37^{\circ} \mathrm{C} / 24$ hours. This study was carried out using Kirby Bauer Disc diffusion method $^{(15)}$. The inhibitory activity was indicated by the diameter size of the clear zone.

\section{RESULT AND DISCUSSION}

\section{Characterization of Ligand (PTMN) UV-Vis Spectrum}

The UV-Vis spectral data of PTMN showed intense peaks at 342, 398 and $491 \mathrm{~nm}$. These are due to $\mathrm{n} \rightarrow \pi^{*}$ and $\pi \rightarrow \pi^{*}$ transitions of conjugated $\varpi$-bonding systems in ligand (Figure 4).

\section{FTIR Spectral Data}

The FTIR spectrum of PTMN (Fig. 5) showed stretching band at $3058 \mathrm{~cm}^{-1}$ which was assigned to the absorption of $\mathrm{C}-\mathrm{H}$ groups for aromatic ring. The second peak at $1602 \mathrm{~cm}^{-1}$ was observed as $\mathrm{C}=\mathrm{N}$ stretching frequencies in the azomethine group which indicated $\mathrm{NH}$ group from tetrazole moeity was associated with $\mathrm{C}$ atom of naphthaldehyde gave Schiff base formation.

\section{Mass Spectral Data}

The mass spectrum of PTMN exhibited a high intense base peak observed at $\mathrm{m} / \mathrm{z}=316$ which indicated $M+1$ peak. It is expected that the spectra shows the existence of quasi molecular ion $(\mathrm{M}+\mathrm{H})^{+}$.

\section{${ }^{1} \mathrm{H}-\mathrm{NMR}$ Spectral Data}

The ${ }^{1} \mathrm{H}-\mathrm{NMR}$ spectrum of PTMN was measured in $\mathrm{CDCl}_{3}$ solvent. The spectrum showed signal at $\delta 13.8 \mathrm{ppm}$ corresponded to the proton of $\mathrm{OH}$ group bound to naphthaldehyde moeity. Many signal in the region $\delta=7.2-8.4 \mathrm{ppm}$ could be attributed to 5 protons of aromatic ring tetrazole moiety and 6 protons of naphthaldehyde rings. The signal at $\delta$ 10.4 was assigned to azomethine proton $(\mathrm{N}=\mathrm{CH})$.

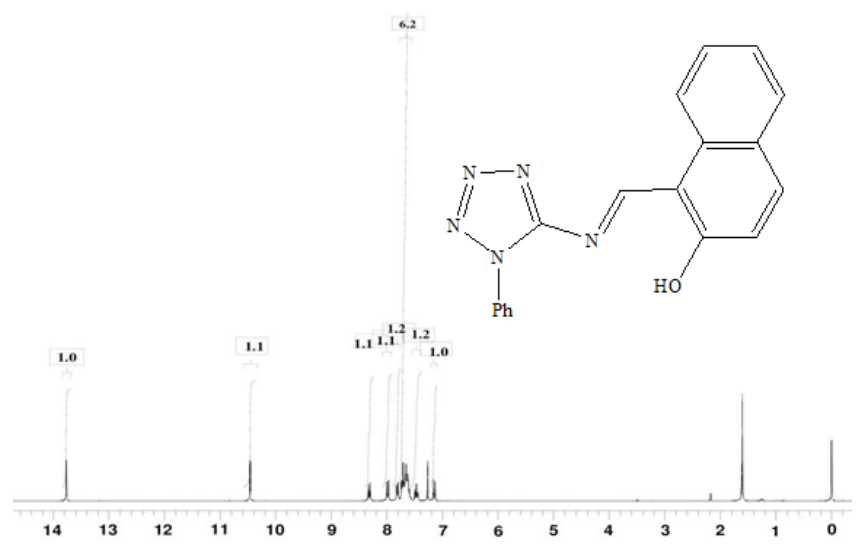

Fig. 1. ${ }^{1} \mathrm{H}-\mathrm{NMR}$ Spectrum of PTMN 


\section{Equilibrium Studies}

The measurement of $\mathrm{pH}$ value of PTMN ligand was performed in $70 \%$ dioxane-water medium at $33^{\circ} \mathrm{C}$ and $0.1 \mathrm{M}\left(\mathrm{KNO}_{3}\right)$ ionic strength. The average number of protons associated per ligand $\left(n_{A}\right)$ were calculated by Irving-Rossetti method ${ }^{16}$. From the titration data, the proton-ligand dissociation constant has been determined by the linear plot of $\log \left(1-n_{A}\right) / n_{A}$ vs pH (Fig. 2). The curves showed the presence of one dissociable proton corresponds to $-\mathrm{OH}$ group of PTMN. The figure shows that the calculated pKa value is 9.16 , which means that the ligand has a greater tendency to dissociate a proton. The $\mathrm{pH}$ metric titrations were also performed with metal ion solutions of $\mathrm{Cu}(\mathrm{II})$ and $\mathrm{Co}(\mathrm{II}))$ in $70 \%$ dioxane-water medium at $33^{\circ} \mathrm{C}$ and $0.1 \mathrm{M} \mathrm{KNO}_{3}$ ionic strength. The formation of complexes while the titration proceeds is identified by the shape of the titration curve. The curve clearly states that stability of the compound increases by the released of dissociable proton.

\section{Spectrophotometry Studies}

Metal ligand composition of $\mathrm{Cu}$ (II) and Co(II) complex was determined spectrophotometrically by applying Job's continuous-variation method ${ }^{17,18}$. The total volume of ligand and metal was kept constant by varying metal and ligand volume ratio. By measuring the absorbance for series of solutions, the exact composition of metal complex can be obtained. A graph is plotted between mole fraction of ligand on $x$ axis and absorbance on y axis. The potentiometric titration shows the released of 1 protons by phenolic hydroxyl group $(-\mathrm{OH})$ donor site. The interpolation plot of Job's method showed 0.5 mole fraction signified the formation of (M:L) 1:1 ratio between metal and PTMN ligand (Fig.3). It assumes that 1 metal binds with 1 PTMN ligands with its oxygen and nitrogen donor sites. Generally, metal complexes with the formation constants greater than 106 are stable over a long range of $\mathrm{pH}$ including high $\mathrm{pH}$ values ${ }^{19}$. Therefore, the complexes in this study have stability constants over 106 were assumed that the complexes are suitable for the use in chelation therapy in that do not dissociate in the gastrointestinal tract or inside any organs and can be excreted from the body as metal complexes.

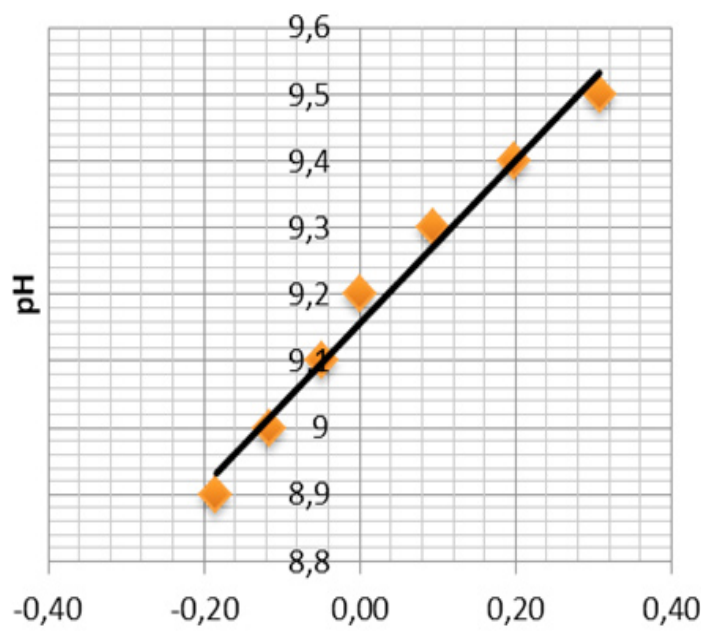

Fig. 2. Plot of $\log \left(1-n_{A}\right) / n_{A}$ vs pH of PTMN in $70 \% v / v$ dioxane-water medium

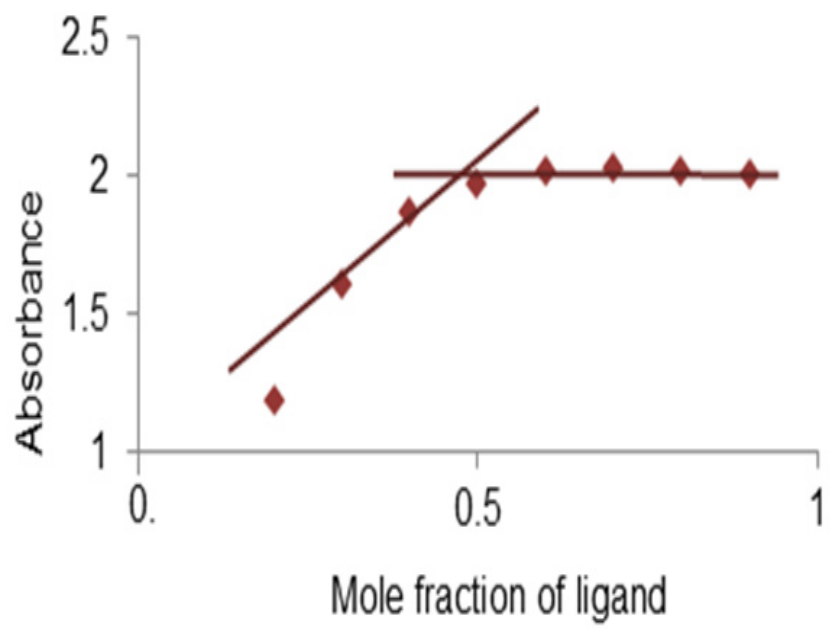

Fig 3. Plot of mole fraction of ligand vs absorbance 
Characterization of $\left[\mathrm{Cu}(\mathrm{PTMN}) \mathrm{ClH}_{2} \mathrm{O}\right]$ and [Co(PTMN) $\left.\mathrm{ClH}_{2} \mathrm{O}\right]$ UV-Vis Spectrum

The UV-Visible spectrum of ligand showed absorption of 342,398 and $491 \mathrm{~nm}$, and the spectra were shifted to a longer absorbance (Hyperchromic shift). The shifted of the spectrum occurred because of LMCT transition upon coordination ${ }^{20}$. [Cu(PTMN)
$\mathrm{ClH}_{2} \mathrm{O}$ complex displayed absorption peak at 318, 368 and $414 \mathrm{~nm}$. These are assigned to $n \rightarrow \pi^{\star}, \pi \rightarrow \pi^{\star}$ and $d-d$ transition respectively. The spin allowed (d-d) transition band is proposed to ${ }^{2} \mathrm{~B}_{1} \mathrm{~g} \rightarrow{ }^{2} \mathrm{~A}_{1} \mathrm{~g}$ transition ${ }^{21}$. [Co(PTMN) $\mathrm{ClH}_{2} \mathrm{O}$ ] complex exhibited absorption peak at 272, 401 and $419 \mathrm{~nm}$. These can be identified as $n \rightarrow \pi^{*}, \pi \rightarrow \pi^{*}$ and ${ }^{4} \mathrm{~A}_{2} \rightarrow{ }^{4} \mathrm{~T}_{1}$ transition respectively.

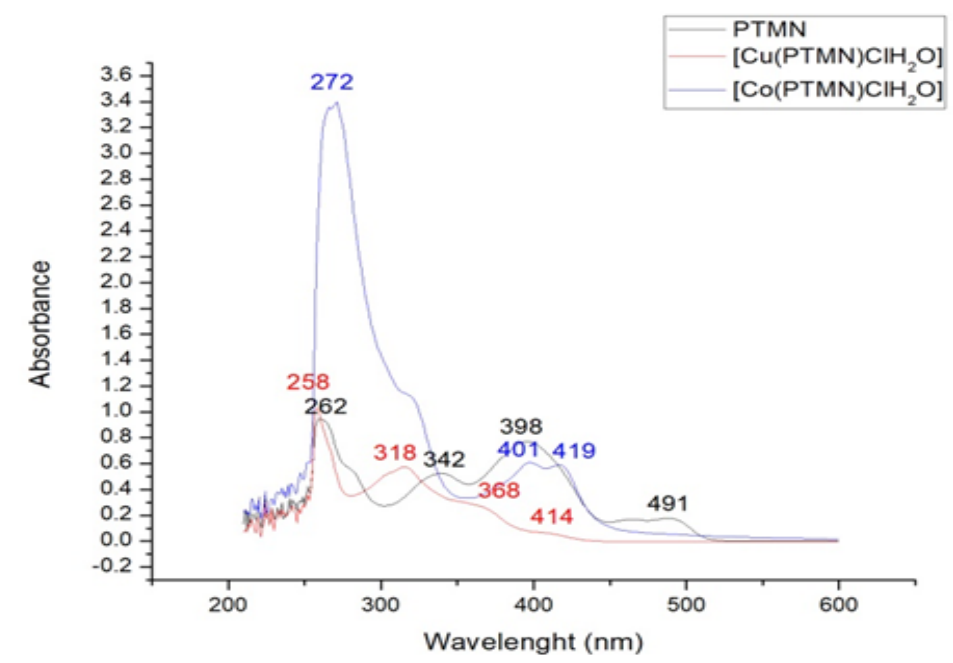

Fig. 4. UV-Vis spectrum of PTMN, $\left[\mathrm{Cu}(\mathrm{PTMN}) \mathrm{ClH}_{2} \mathrm{O}\right]$ and $\left[\mathrm{Co}(\mathrm{PTMN}) \mathrm{CIH}_{2} \mathrm{O}\right]$

\section{Mass Spectral Data}

The mass spectrum of [Cu(PTMN) $\left.\mathrm{ClH}_{2} \mathrm{O}\right]$ exhibited a dominant peak at $\mathrm{m} / \mathrm{z} 434$ which depicted evidence of [M+2] ionization value. The [Co(PTMN) $\mathrm{ClH} 2 \mathrm{O}]$ mass spectrum showed a dominant peak at $\mathrm{m} / \mathrm{z} 429$ which indicated [M+2] peak.

\section{FTIR Spectral Data}

The FTIR stretching frequencies of ligand (PTMN), [Cu(PTMN)ClH ${ }_{2} \mathrm{O}$ and [Co(PTMN) $\left.\mathrm{ClH}_{2} \mathrm{O}\right]$ complexes are compared in the Table below.

FTIR spectrum exhibited new bands at
$690 \mathrm{~cm}^{-1}$ and $536 \mathrm{~cm}^{-1}$ which were assigned to $\mathrm{vM}-\mathrm{O}$ for $\mathrm{Cu}$ (II) and $\mathrm{Co}$ (II) complexes respectively. These indicate that the oxygen were involved in coordination with metal ions. The azomethine group $(-\mathrm{N}=\mathrm{CH}-)$ stretching frequency for [Cu(PTMN) $\mathrm{ClH} 2 \mathrm{O}]$ and [Co(PTMN) $\mathrm{ClH}_{2} \mathrm{O}$ ] complexes shifted slightly to a higher values into $1635 \mathrm{~cm}^{-1}$ and $1620 \mathrm{~cm}^{-1}$ respectively. These suggest that PTMN ligand is coordinated through $-\mathrm{N}=\mathrm{C}-$ to the metals and also confirm that all metals coordinated directly to $\mathrm{N}$ atom of tetrazole moeity. Peak at $3200-3400 \mathrm{~cm}^{-1}$ indicated the presence of $\mathrm{H}_{2} \mathrm{O}$ molecule.

Table 1: IR stretching frequencies of PTMN, [Cu(PTMN) $\left.\mathrm{ClH}_{2} \mathrm{O}\right]$ and [Co(PTMN) $\left.\mathrm{ClH}_{2} \mathrm{O}\right]$ complexes

\begin{tabular}{lcccc}
\hline Compound & \multicolumn{4}{c}{ Stretching frequencies } \\
& $\mathrm{v}_{\mathrm{CH}=\mathrm{N}}$ & $\mathrm{v}_{\mathrm{M}-\mathrm{N}}$ & $\mathrm{v}_{\mathrm{M}-\mathrm{O}}$ & $\mathrm{v}_{\mathrm{OH} / \mathrm{H} 2 \mathrm{O}}$ \\
\hline PTMN & $1602 \mathrm{~cm}^{-1}$ & - & - & - \\
{$\left[\mathrm{Cu}(\mathrm{PTMN}) \mathrm{ClH}_{2} \mathrm{O}\right]$} & $1635 \mathrm{~cm}^{-1}$ & $478 \mathrm{~cm}^{-1}$ & $690 \mathrm{~cm}^{-1}$ & $3284 \mathrm{~cm}^{-1}$ \\
{$\left[\mathrm{Co}(\mathrm{PTMN}) \mathrm{ClH}_{2} \mathrm{O}\right]$} & $1620 \mathrm{~cm}^{-1}$ & $428 \mathrm{~cm}^{-1}$ & $536 \mathrm{~cm}^{-1}$ & $3132 \mathrm{~cm}^{-1}$ \\
\hline
\end{tabular}




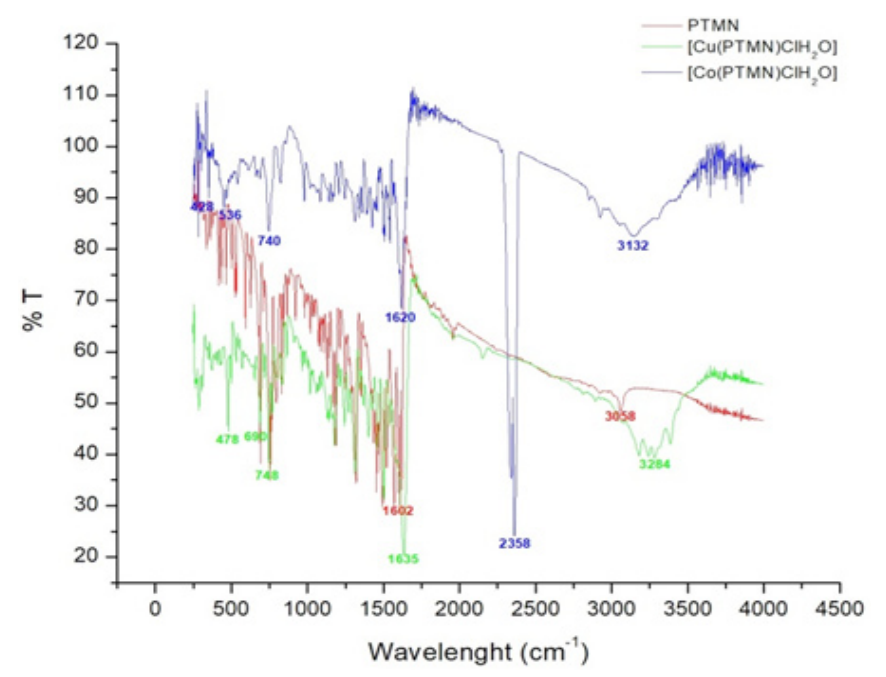

Fig. 5. IR spectrum of PTMN, [Cu(PTMN) $\left.\mathrm{ClH}_{2} \mathrm{O}\right]$ and $\left[\mathrm{Co}(\mathrm{PTMN}) \mathrm{CIH}_{2} \mathrm{O}\right]$

\section{Thermal Analysis (TGA/DTA)}

Thermogravimetric analysis (TGA) curve of $\left[\mathrm{Cu}(\mathrm{PTMN}) \mathrm{ClH}_{2} \mathrm{O}\right]$ showed percentage of weight loss. The beginning process of decomposition (first stage) was started at $187^{\circ} \mathrm{C}$. It is exhibited the decomposition of coordinated water, chloride and partial decomposition of ligand at $225^{\circ} \mathrm{C}$. The second stage showed the $50.4 \%$ weight loss which is due to the total loss of ligand at $300-480^{\circ} \mathrm{C}$. DTA data presented that the first stage was an exothermic reaction at $\operatorname{tmin}=187^{\circ} \mathrm{C}$ which is related to the explosive matter or pyrolytic nature of tetrazole imine base moiety. The remaining residue was $28.8 \%$ corresponding to the metal oxide formation.

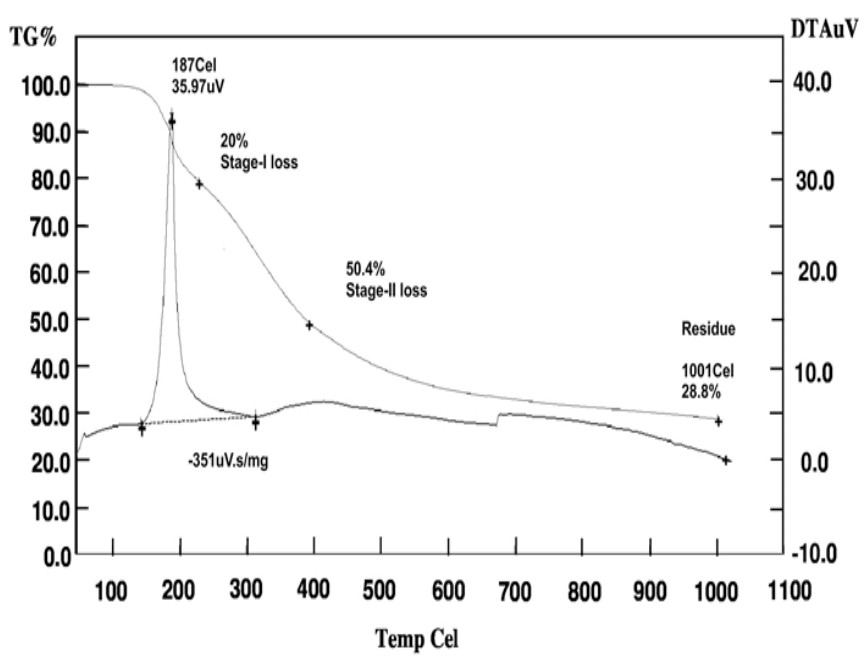

Fig. 6. TGA and DTA curve of [Cu(PTMN)CIH2O]

Thermo-gravimetric analysis (TGA) data for $\left[\mathrm{Co}(\mathrm{PTMN}) \mathrm{ClH}_{2} \mathrm{O}\right]$ showed percentage of decomposition. In the beginning process started from $200^{\circ} \mathrm{C}$. It was observed as weight loss of water, chloride and partial decomposition of ligand. This loss was analyzed as an endothermic reaction through DTA data at $\operatorname{tmin}\urcorner=227^{\circ} \mathrm{C}$. The second stage exhibited total exothermic decomposition of ligand around $330^{\circ} \mathrm{C}-500^{\circ} \mathrm{C}$. This peak can be assumed as pyrolytic properties of tetrazole imine base moiety. The percentage of the last residue is $18.9 \%$ corresponds to metal oxide residue. 


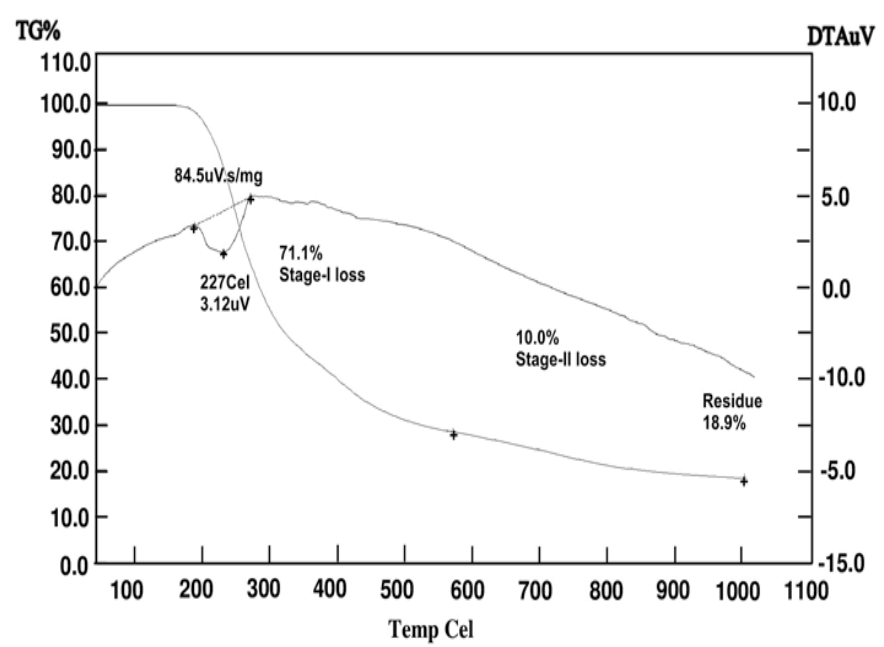

Fig. 7. TGA and DTA curve of $\left[\mathrm{Co}(\mathrm{PTMN}) \mathrm{ClH}_{2} \mathrm{O}\right.$

\section{SEM and EDX Studies}

Scanning Electron Microscope (SEM) was performed to exhibit the surface morphology of PTMN ligand and its complexes. The morphology of PTMN ligand is viewed as coral form with the resolution of $1 \mathrm{~mm}$. There is a noticeable change in the morphology of the PTMN ligand due to the coordinated metal ions. The surface morphology of $\left[\mathrm{Cu}(\mathrm{PTMN}) \mathrm{ClH}_{2} \mathrm{O}\right]$ appeared more roughness than $\left[\mathrm{Co}(\mathrm{PTMN}) \mathrm{ClH}_{2} \mathrm{O}\right]$ by the image of $100 \mu \mathrm{m}$ and $1 \mu \mathrm{m}$ respectively. The biological activity results revealed that the surface with larger roughness showed stronger antimicrobial potential compared to smoother one. SEM images found that the complexes are $\mu \mathrm{m}$ in size.

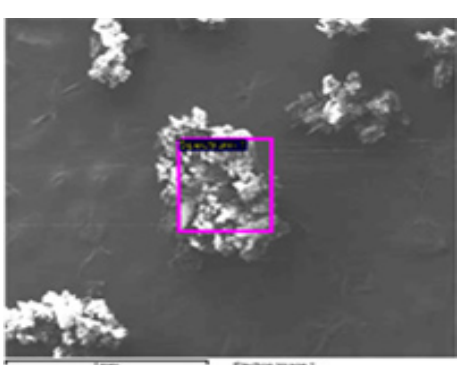

(a)

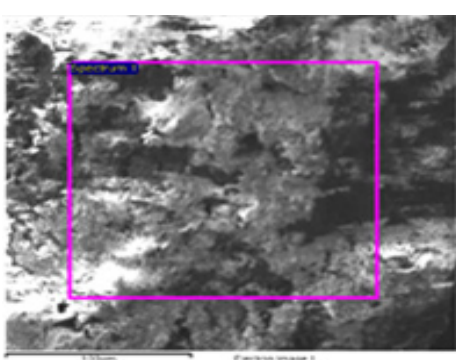

(b)

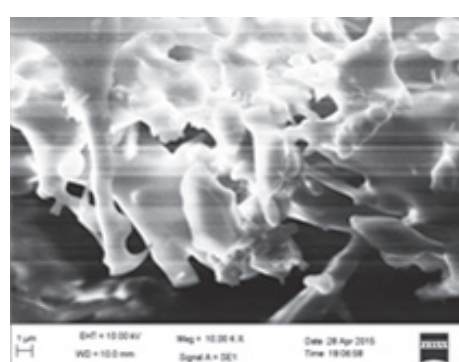

(c)

Fig. 8. SEM Image of (a) PTMN ligand (b) [Cu(PTMN)ClH ${ }_{2} \mathrm{O}$ (c) $\left[\mathrm{Co}(\mathrm{PTMN}) \mathrm{ClH}_{2} \mathrm{O}\right]$

On the other hand, Energy Dispersive X-Ray (EDX) analysis was carried out to identify elements in ligand and its metal complexes. EDX analysis results showed the existence of metal ions $\mathrm{Cu}(\mathrm{II})$ and $\mathrm{Co}(\mathrm{II}))$ elements in the complexes. It is confirmed that the formation between ligand and metal ions occurred.

The chemical composition obtained by Energy Dispersive X-Ray (EDX) analysis on PTMN ligand indicated mainly $\mathrm{C}, \mathrm{N}$, and $\mathrm{O}$ (Fig. 9.a). When the ligand coordinated with metals to form complexes, EDX analysis showed the appearance of $\mathrm{Cu}(\mathrm{II})$ and
Co(II) spectrum. The analysis exhibited the spectrum of $\mathrm{Cl}$ element on each complex, signified that the metal ions have four binding sites.

\section{Antimicrobial Activity Test}

Antimicrobial activity test was determined by using disc diffusion method. The size of inhibition zone depends on how effective the compound by stopping the growth of the microba. The effectiveness of free ligand and metal complexes ac antimicrobial agent were tested against non-resistant strain of Gram positive (Bacillus subtilis and Staphylococcus aureus), Gram negative (Klebsiella pneumoniae, 
Pseudomonas aeruginosa and Escherichia coli) bacteria and yepda (Saccharomyces cerevisiae) on nutrient agar medium. The incubation was performed at $37^{\circ} \mathrm{C} / 24$ hours.

The activity of $\left[\mathrm{Cu}(\mathrm{PTMN}) \mathrm{ClH}_{2} \mathrm{O}\right]$ and [Co(PTMN) $\mathrm{ClH}_{2} \mathrm{O}$ ] complexes is relatively higher than free PTMN ligand revealed that the proper result may be due to the presence of Schiff base formation

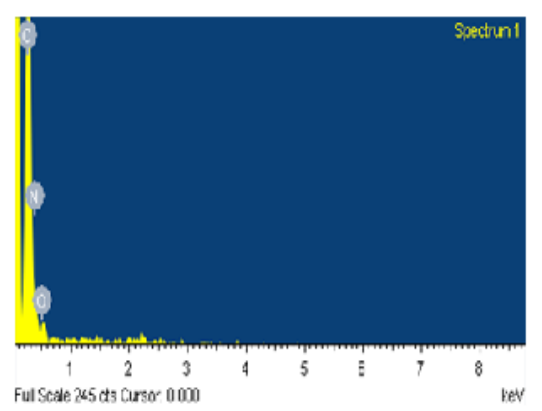

(a) in the complexes. The following activity is arranged as: $\left[\mathrm{Cu}(\mathrm{PTMN}) \mathrm{ClH}_{2} \mathrm{O}\right]>\left[\mathrm{Co}(\mathrm{PTMN}) \mathrm{ClH}_{2} \mathrm{O}\right]>\mathrm{PTMN}$. The results informed that the complexes possesses more ability to inhibit the growth of the microba which leads to the death of the microba. It is found that $\left[\mathrm{Cu}(\mathrm{PTMN}) \mathrm{ClH}_{2} \mathrm{O}\right]$ with more roughness surface showed more potential activity to inhibit the growth of microba compared to [Co(PTMN) $\mathrm{ClH}_{2} \mathrm{O}$ ].

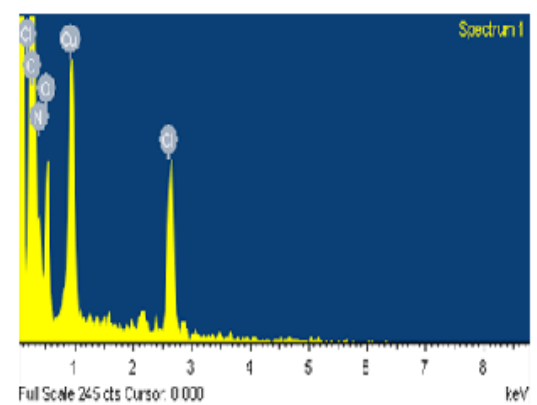

(b)

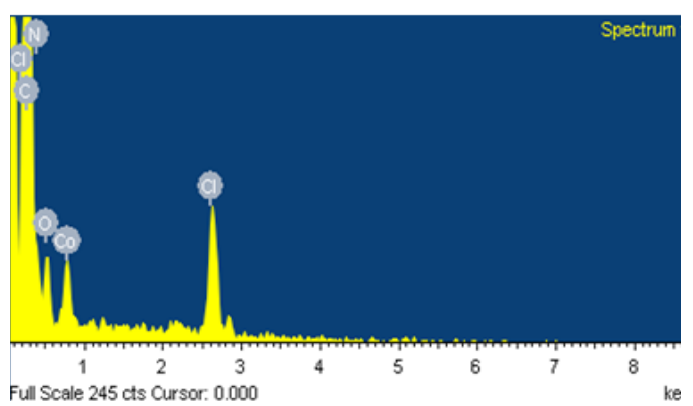

(c)

Fig. 9. EDX spectrum of (a) PTMN ligand (b) $\left[\mathrm{Cu}(\mathrm{PTMN}) \mathrm{ClH}_{2} \mathrm{O}\right]$ (c) $\left[\mathrm{Co}(\mathrm{PTMN}) \mathrm{ClH}_{2} \mathrm{O}\right]$

Table 2. Chemical composition based on EDX analysis.

\begin{tabular}{lccc}
\hline Name of Compound & Element & Weight\% & Atomic\% \\
\hline Ligand & C K & 45.80 & 50.21 \\
& N K & 44.18 & 41.54 \\
& O K & 10.02 & 8.25 \\
& Totals & 100.00 & \\
[Cu(PTMN)CIH2O] & C K & 21.92 & 41.84 \\
& O K & 22.31 & 31.96 \\
& Cl K & 21.30 & 13.77 \\
& Cu L & 34.47 & 12.43 \\
& Totals & 100.00 & \\
[Co(PTMN)CIH2O] & C K & 87.55 & 127.39 \\
& N K & -49.55 & -61.83 \\
& O K & 14.99 & 16.37 \\
& Cl K & 20.99 & 10.35 \\
& Co L & 26.02 & 7.72 \\
& Totals & 100.00 & \\
\hline
\end{tabular}


Table 3: Inhibition zone diameter of PTMN [Cu(PTMN) $\left.\mathrm{CIH}_{2} \mathrm{O}\right]$ and [Co(PTMN) $\mathrm{ClH}_{2} \mathrm{O}$ ]

\begin{tabular}{lccc}
\hline Name of organisms & \multicolumn{3}{c}{ Inhibition Zone (mm) } \\
\hline & PTMN (Ligand) & Cu(II) complex & Co(II) complex \\
\hline Bacillus subtilis & 3 & 6 & 4 \\
S. aureus & 4 & 12 & 8 \\
E. coli & 2 & 9 & 3 \\
K. pneumoniae & 2 & 8 & 4 \\
P. aeruginosa & 2 & 6 & 3 \\
Yepda & 2 & 6 & 4 \\
\hline
\end{tabular}

\section{CONCLUSION}

PTMN, [Cu(PTMN)ClH $\left.{ }_{2} \mathrm{O}\right]$ and [Co(PTMN) $\mathrm{ClH}_{2} \mathrm{O}$ ] complexes have been synthesized and characterized by various spectroanalytical method. Spectroanalytical studies revealed that the molecular mass of the ligand is 315 which is shown as $\mathrm{m} / \mathrm{z}=316$ $(M+1)$ peak. It is an agreement with the addition of molecular mass of 1 -phenyl-1 $\mathrm{H}$-tetrazol-5-amine, 2-hydroxy-1-naphthaldehyde substracting with water molecule. Furthermore, UV-Vis, IR and ${ }^{1} \mathrm{H}-\mathrm{NMR}$ spectral data showed particular bonding which correspond to $-\mathrm{N}=\mathrm{CH}-, \mathrm{CH}, \mathrm{OH}$ and the presence of aromatic moiety in the PTMN ligand. Mass spectral data of [ $\left.\mathrm{Cu}(\mathrm{PTMN}) \mathrm{ClH}_{2} \mathrm{O}\right]$ and [ $\mathrm{Co}(\mathrm{PTMN})$ $\mathrm{ClH}_{2} \mathrm{O}$ ] exhibited the dominant peaks at 434 and 429 respectively. IR and UV-Vis bands of metal complexes revealed the occurance of metal-ligand interaction. By using all the data, it is suggested that $\mathrm{Cu}(\mathrm{II})$ and $\mathrm{Co}(\mathrm{II})$ form complexes with $\mathrm{N}$ - and $\mathrm{O}$ - binding sites of the PTMN ligand. Antimicrobial activity studies revealed that the presence of metal enhanced the activity than the free ligand due to the Schiff base formation of the complexes. The antimicrobial activity of $\left[\mathrm{Cu}(\mathrm{PTMN}) \mathrm{ClH}_{2} \mathrm{O}\right]$ is more potential than $\left[\mathrm{Co}(\mathrm{PTMN}) \mathrm{ClH}_{2} \mathrm{O}\right]$ complex.

\section{ACKNOWLEDGEMENT}

The authors gratefully thank Institut Teknologi Sumatera, Department of Chemistry, Department of Microbiology and Department of Central Facilities for Research \& Development (CFRD) Osmania University for providing facilities and financial support.

\section{REFERENCES}

1. Makosza M. and Wojciechowski K. Heterocycles., 2014, 88, 75-101.

2. Zhai C.; Zhao L.; Hao X.Y.; Shi Y.J; Xu D.; Yang Z.Y; Wang Z.K; Chen D.Y; Li Q.Y and Yang G.W. Inorg Chem Commun., 2017, 84, 150-2.

3. Nemecek J.; Sychra P.; Machácek M.; Benková M.; Karabanovich G.; Konecná K.; Kavková V; Stolacíková J; Hrabálek A; Vávrová K; Soukup O; Roh J and Klimešová V. Eur J Med Chem., 2017, 130, 419-32.

4. Łukowska-Chojnacka E.; Mierzejewska J.; Milner-Krawczyk M.; Bondaryk M. and Staniszewska M. Bioorganic Med Chem., 2016, 24, 6058-65.

5. Surendra Babu M.S.; Rao B.U.; Krishna V.;
Mustafa S. and Rao G.N. J Saudi Chem Soc., 2017, 21, 291-9.

6. Pandey S.; Agarwal P.; Srivastava K.; RajaKumar S.; Puri S.K.; Verma P.; J.K. Saxena; Sharma A; Lal J and Chauhan P.M.S. Eur J Med Chem., 2013, 66, 69-81.

7. Chermahini Z.J.; Chermahini A.N.; Dabbagh H.A. and Teimouri A. J Energy Chem., 2015, 24, 770-8.

8. Ponnuvel K.; Padmini V. and Sribalan R.A. Sensors Actuators, B Chem., 2016, 222, 605-11.

9. Frija L.M.T.; Alegria E.C.B.A.; Sutradhar M.; Cristiano M.L.S.; Ismael A.; Kopylovich M.N and Pombeiro A. J. L. J Mol Catal A Chem., 2016, 425, 283-90. 
10. Faria J.V.; Dos Santos M.S.; Bernardino A.M.R.; Becker K.M.; Machado G.M.C.; Rodrigues R.F.; Cavalheiro M.M.C and Leon L.L. Bioorganic Med Chem Lett., 2013, 23, 6310-2.

11. Al-Majidi S.M.H. J Saudi Chem Soc., 2014, 18, 893-901.

12. Harit T.; Bellaouchi R.; Mokhtari C.; El Bali B.; Asehraou A. and Malek F. Tetrahedron., 2017, 73, 5138-43.

13. Pan J.; Jiang F.L.; Wu M.Y.; Chen L.; Wan X.Y.; Yang Y.; Xue H; Yu M.X and Honget M.C. Inorg Chem Commun., 2015, 56, 129-32.

14. Palreddy R; Mohmed J; Narsimha N; Aparna B and Mariyam. Journal of Materials Science and Chemical Engineering., 2015, 135, 45-59.
15. Bauer, A.W.; Kirby, W.M.M.; Sherris, J.C. and Turck, M. Amer. J. Clin. Pathol., 1966, 45, 493-496.

16. H.M Irving and H.S Rossotti. J Chem Soc., 1952, 2904, 2904-10.

17. Job, P. Ann. Chim.,1928, 9, 113-203.

18. Joseph S. R.; Laura L. T.; Evan H. T. and David B. C. Angew Chem Int Ed Engl., 2013, 52, 11998-12013.

19. Furia, T.E. CRC Press, Boca Raton, Florida, USA. 1972.

20. Jamil W.; Solangi S.; Ali M.; Khan K.M.; Taha M. and Khuhawar M.Y. Arab. J. Chem., 2015, 10, 1-8.

21. Sivasankaran N.; Dasan A. and Joseyphus, R. S. J Saudi Chem Soc., 2012, 16, 83-88. 